\title{
LITERASI MEDIA SOSIAL HUMAS PEMERINTAH DAERAH
}

\author{
Novian Anata Putra \\ novio1o@kominfo.go.id \\ Balai Pengkajian dan Pengembangan Komunikasi Dan Informatika (BPPKI) Yogyakarta,
}

\begin{abstract}
Abstrack
Nowadays, the government is trying to fight against hoax. One of them, President Joko Widodo instructed to improve the function of government public relations and information managers to ward off hoaxes spread quickly in social media. However, it will work if government public relations officers have adequate social media literacy skills. Social media literacy is considered the basis for understanding the characteristics of new media. The aim of this research is to examine the level of social meda literacy among local government public relations at present. Quantitative approach with survey method will be used in this research. The study was conducted in eight local governments that have held anti-hoax declarations. The eight local governments are: Semarang regency, Semarang city, Wonosobo regency, Solo city, Banyumas regency, Blora regency, Yogyakarta city and Province of Bali. Based on the research analysis, it can be concluded that the managers of social media public relations of local governments who have held anti-hoax declaration are already have enough social media literacy. The local government needs to increase knowledge and skills that are technical about new media and social media in order to optimize the function and the role of local government public relations in the effort to ward off hoaxes. While the hardest part of social media literacy, which always involves the criticality literacy media, most of local government public relations have already master it.
\end{abstract}

\begin{abstract}
Abstrak
Pemerintah saat ini berusaha melawan berita-berita hoax. Salah satunya, Presiden Joko Widodo menginstruksikan untuk meningkatkan fungsi humas pemerintah dan pengelola informasi untuk menangkal hoax yang tersebar cepat di media sosial. Namun, hal itu akan berhasil jika para petugas humas pemerintah mempunyai kecakapan literasi media sosial yang memadai. Literasi media sosial dianggap sebagai dasar memahami karakteristik media baru. Penelitian ini akan melihat sejauh mana tingkat literasi media sosial di kalangan humas pemerintah daerah saat ini. Penelitian menggunakan pendekatan kuantitatif dengan metode survei. Penelitian dilakukan di delapan pemerintah daerah yang telah menggelar deklarasi anti hoax, yakni Kota Semarang, Kabupaten Semarang, Kabupaten Wonosobo, Kota Solo, Kabupaten Banyumas, Kabupaten Blora, Kota Yogyakarta, dan Provinsi Bali. Dengan tidak adanya nilai rendah, maka dapat disimpulkan bahwa para pengelola media sosial humas pemerintah daerah yang telah menggelar deklarasi anti hoax telah memiliki literasi media sosial yang cukup. Untuk mengoptimalkan fungsi dan peran humas pemerintah daerah dalam usaha menangkal hoax hanya perlu meningkatkan pengetahuan dan ketrampilan yang sifatnya teknis tentang media baru dan media sosial. Sedangkan bagian tersulit dari literasi media sosial, yaitu selalu melibatkan tingkat kekritisan para pegawai humas pemerintah daerah dalam aktifitas media sosial, telah banyak yang menguasainya.
\end{abstract}

Keywords: New Media, Social Media Literacy, Local Government Public Relation 


\section{PENDAHULUAN}

"Untuk mengatasi lemahnya manajemen komunikasi pemerintah, sudah waktunya bagi Presiden Joko

Widodo perlu untuk mendorong atau mewajibkan semua kementerian dan lembaga negara, para gubernur, bupati, dan wali kota untuk lebih sigap merespons hoax atau berita bohong. Kekacauan bisa ditangkal dan tertib umum akan terjaga jika aparatur pemerintah pusat dan daerah sigap meluruskan berita bohong."

Pernyataan tersebut merupakan saran ketua komisi III DPR RI kepada Presiden Joko Widodo untuk mendorong biro humas dan PPID di seluruh kementerian dan lembaga serta institusi turunannya lebih responsif dalam menangkal hoax (news.detik.com, 9/1/2017). Saran ini dirasa tepat jika kita melihat kembali peran yang sangat penting (pivotal role) dari humas pemerintah. Dalam sistem demokrasi, pemerintah tidak saja harusmenyampaikan kebijakan kepadawarga negara, tapi sekaligus harus mendorong partisipasi publik dalam skala luas. Oleh karena itu, komunikasi antara organisasi pemerintah dan warga negara harus dikelola dengan baik. Humas pemerintah memunyai peran dalam pengelolaan komunikasi tersebut. Public relations (humas) sendiri, dalam Cutlip, dkk (200o, hal. 4), memiliki fungsi manajemen yang secara khusus mendukung terbentuknya saling pengertian, pemahaman, penerimaan dan kerja sama antara organisasi dengan publiknya. Baik saling pengertian (mutual understanding), penerimaan ataupun kerja sama hanya mungkin melalui komunikasi, dan hal itu berarti membutuhkan suatu proses komunikasi yang jujur dan saling percaya

Setidaknya, ada dua tantangan yang dihadapi oleh humas pemerintah saat ini dibandingkan beberapa dekade lalu. Pertama, demokratisasi politik. Demokratisasi politik ini telah menciptakan suatu sistem dimana media dan masyarakat bisa 'berteriak' melawan pemerintah. Media bahkan acapkali membangun sikap bermusuhan kepada pemerintah ketika terdapat kebijakan yang tidak sesuai dengan aspirasi warga negara. Kedua, perkembangan teknologi komunikasi sudah merambah pada tahapan new media. Teknologi media baru ini memunyai karakteristik yang hampir sama sekali berbeda dibandingkan dengan media lama (old media). Dalam media baru, batas antara penerima dan pemroduksi pesan menjadi kabur.

Penelitian ini berangkat dari pemahanan bahwa popularitas media sosial semakin meningkat karena adanya kombinasi antara perkembangan teknologi dan perubahan sosial. Namun, ada perbedaan dalam hal cara orang menggunakan media sosial dan tingkat literasi mereka. Platform media baru terutama media sosial mulai masuk ke dalam ranah kehidupan sehari-hari, mempengaruhi interaksi informal masyarakat, struktur kelembagaan, dan rutinitas profesional. Teknologi media baru telah mendorong lanskap media berubah drastis dan dramatis. Eshet-Alkalai \& Soffer (2012, p. 1) berpendapat dalam sebuah editorial, teknologi digital (media sosial, multimedia dan komunikasi) telah merambah hampir setiap aspek kehidupan kita. Perubahan ini menyebabkan bentuk-bentuk baru dari praktek budaya di terutama budaya kerja. Teknologi baru membuat media bahkan lebih signifikan dan berpengaruh dari sebelumnya dalam sejarah manusia (Berger \& McDougall, 2010). Oleh karena itu, seseorang profesional saat ini dituntut harus melek media baru untuk dapat sepenuhnya menjalankan fungsi profesinya dalam masyarakat.

Para ilmuwan sosial telah menyadari pentingnya literasi media baru ini, dan perannya bagi kesuksesan profesional. Schmidt-Herta dan Root (2014), misalnya, menyatakan bahwa literasi media sangat dibutuhkan sebagai keterampilan penting dalam kehidupan para profesional. Lebih khusus, karyawan atau tenaga kerja dengan latar belakang akademik diharapkan mampu menggunakan teknologi informasi dalam kerja yang mereka lakukan sehari-hari dalam suatu carayang profesional. Gagasan ini sekali lagi menegaskan bahwa para profesional di 
bidang komunikasi, termasuk para pengelola komunikasi pada humas pemerintah, harus memunyai kapasitas untuk menggunakan teknologi secara benar. Terlebih, bagi pegawai humas pemerintah yang sehari-hari, merujuk Grunig dan Hunt (1992), mengelola komunikasi antara organisasi (pemerintah) dengan publiknya (warga masyarakat).

Artinya, dengan karakteristik media baru yang hampir sama sekali berbeda dibandingkan dengan bentuk-bentuk komunikasi lama (old communication), menuntut prasyarat tertentu bagi para pengelola komunikasi pada humas pemerintah daerah agar mampu menggunakan media baru ini secara efektif. Dengan kata lain, para petugas humas membutuhkan suatu literasi media baru media baru dalam mengakses dan menggunakan media baru dan media sosial untuk pengelolaan komunikasi.

\section{Media Baru: Redefinisi Konsep Media}

Jenkins (2004) menegaskan bahwa media konvergensi di era media baru lebih dari sekedar pergeseran teknologi. Konvergensi akan mengubah hubungan antara teknologi yang sudah ada, industri, pasar, genre dan penonton. Konvergensi media merupakan cara di mana masyarakat akan bermain menentukan keseimbangan kekuasaan dalam era media baru (Jenkins, 2004). Dalam pandangan Jenkins, dengan perkembangan konvergensi media, akan muncul dua macam kekuatan media: satu datang melalui konglomerasi media media, di mana setiap kekuasan atas informasi hanya dimiliki para pemodal besar; yang lain datang melalui kecerdasan kolektif, di mana otoritas pesan dipandang relevan dengan jaringan yang lebih bebas dari keberagaman publik. Sederhananya, konsumen nantinya akan mempengaruhi produksi dan distribusi konten media.

Dalam sebuah jurnal, Levy (2010) memaparkan konsep kecerdasan kolektif yang dipake oleh Jenkins sebagai kemampuan kolektif manusia untuk terlibat dalam kerjasama intelektual untuk mencipta maupun dalam berinovasi. Lin dkk., (2013) juga menegaskan kecerdasan kolektif tidak dapat dipisahkan dengan budaya partisipatif di era itu. Bahwa sebuah pemahaman, pengetahuan, dan intelejensi dibangun dari partisipasi banyak manusia. Di era ini, masyarakat yang terlibat telah menyadari bahwa tidak ada kebenaran yang sebenarbenarnya (dalam media) (Lin, dkk., 2013).

Kecerdasan kolektif ini tidak hanya bermain dalam industri media. Kietzmann dkk., (2011) menyatakan perkembangan media baru khususnya media sosial sangat berdampak signifikan terhadap dunia bisnis seperti reputasi perushaan dan penjualan. Dengan adanya logika kecerdasan kolektif melalui media sosial, tampak bahwa komunikasi korporasi telah mengalami demokratisasi. Kekuasaan penuh dari pemasaran dan humas telah diambil sebagian oleh individu dan komunitas yang menciptakan, membagi, dan mengonsumsi blog maupun cuitan dari media sosial. Namun sampai saat ini masih belum banyak perusahaan yang mulai serius merespon kehadiran media baru ini.

Selain nilai demokratisasi yang didorong kecerdasan kolektif, Kovach dan Rosenstiel (2011) menambahkan implikasi yang harus diwaspadai dari perkembangan media baru. Sebuah tsunami informasi dimana dunia maya saat ini seperti angkasa luas tempat milyaran informasi bertebaran. Jika tidak berhati-hati memeriksa setiap informasi yang ditemui, masyarakat akan mudah tersesat di dalamnya (Kovach \& Rosenstiel, 2011). Meskipun tren informasi menyesatkan, yang saat ini populer dengan sebuatan hoax, telah muncul jauh sebelum media baru hadir. Namun perkembangannya semakin pesat dengan semakin berkembangnya teknologi komunikasi dan informasi. Bahkan ilmu pengetahuan dan sejarah yang telah lama dipahami sebagai kebenaran, di era media baru semua kembali diperdebatkan (Lewandowsky, dkk., 2013). Piliang (2010) menggambarkan fenomena ini dengan konsep realitas semu, yang mampu merubah fantasi, halusinasi, ilusi, atau science-fiction menjadi seolah nyata; mampu mereproduksi ulang masa lalu dan nostalgia; mampu 
melipat-lipat dunia sehingga tak lebih luas dari sebuah genggaman tangan.

Artinya dari seluruh gambaran atas hadirnya media baru ini, perlu adanya sebuah pembaruan konsep atas apa yang disebut melek media baru, atau konsep literasi media baru. Kovach dan Risenstiel mengajukan pendekatan jurnalistik untuk literasi media baru menghadapai banjir informasi. Namun dari penelitian Marchi (2012) menunjukkan bahwa masyarakat khususnya remaja mengabaikan cita-cita dasar jurnalisme profesional, meskipun mereka memahaminya, ketika memilih informasi di dunia maya. Penggiat literasi, Renee Hobbs (2010), dalam sebuah essay juga menggambarkan bahwa news literacy tidak serta merta bekerja dalam era media baru. Artinya perlu sebuah kerangka kerja baru untuk melengkapi pemahaam atas literasi berita dan pendekatan jurnalisme untuk menjadi terliterasi di era media baru.

Buku-buku mengenai literasi media memberikan suatu definisi yang umum mengenai literasi media meskipun definisidefinisi tersebut tidak saling sepakat satu dengan lainnya (Potter, 2004). Namun, pada akhirnya, keseluruhan buku-buku teks literasi media itu mengajarkan suatu hal pokok mengenai literasi media, yakni kemampuan dalam mengakses media secara kritis. Literasi media merupakan suatu kontinum (Potter, 2001) sehingga tidak bisa dikatakan bahwa seseorang telah berada pada derajat literasi yang penuh meskipun ia seorang profesional media. Literasi media selalu berkembang. Literasi media tidak hanya berkaitan dengan persoalan pengetahuan dan skill, tetapi juga suatu state of mind yang memerlukan monitoring secara berkelanjutan (Rosenbaum, dkk., 2008).

\section{Humas Pemerintah dalam}

\section{Perkembangan Teknologi Komunikasi}

Cutlip dkk., (200o, hal. 488) mengemukakan bahwa pemerintah menyentuh hampir semua aspek masyarakat, dan hampirsetiapaspek pemerintahan terkait erat dengan dan bergantung pada hubungan masyarakat. Bahkan, dalam pengertian yang paling nyata, tujuan-tujuan demokrasi itu sendiri, menurut Cutlip, dkk., sangat seiring dengan tujuan-tujuan hubungan masyarakat. Pemerintahan demokrasi yang berhasil senantiasa memelihara hubungan-hubungan dengan konstituen yang didasarkan pada pemahaman bersama (mutual understanding) dan komunikasi dua arah. Ini jelas merefleksikan tujuantujuan diselenggarakannya hubungan masyarakat dalam suatu organisasi, yakni dalam rangka apa yang disebut Grunig dan Hunt (1992), "Managing communication between organization and its public". Dalam pemahaman semacam ini, tidak bisa dipungkiri jika pemerintahan terkait erat dan bergantung dengan hubungan masyarakat. Ini tidak hanya bahwa kebijakan-kebijakan pemerintah harus dikomunikasikan, tapi bahwa keberhasilan pemerintahan demokratis akan sangat ditentukan oleh partisipasi luas masyarakat. Partisipasi hanya mungkin terjadi jika terdapat komunikasi dua arah diantara rakyat dan pemerintah.

Sebagaimana dikemukakan Cutlip, dkk., di atas, hubungan masyarakat barangkali diberi peran dan tanggung jawab lainnya oleh pemerintah, tapi tugas utamanya adalah memastikan aliran informasi secara berkelanjutan kepada publik. Publik ini, dalam pengertian public relations,sering didefinisikan sebagai internal public and external public (Seitel, 2004). Di era sekarang, tantangan sekaligus peluang yang dihadapi oeh pemerintah adalah perkembangan teknologi komunikasi. Khususnya, perkembangan teknologi media baru dalam bentuk media sosial. Oleh karenanya, tidak mengherankan jika penggunaan media sosial dalam sektor publik menjadi topik hangat, dan para administrator pemerintah, termasuk hubungan masyarakat, mulai menggunakan media baru untuk mendorong keterikatan publik dan membangun komunitas (Graham \& Avery, 2013). Merujuk Bertot, dkk., (2010) mengemukakan bahwa kemampuan transformatif media sosial bagi pemerintahan sangatlah signifikan. Sebagai user-generated media, Hand dan Ching 
(2011), mengemukakan bahwa media sosial memungkinkan praktisi public relations dalam pemerintahan mampu memberikan informasi dan mencari masukan-masukan dan opini dari publik yang relevan. Dalam jangka panjang, ini jelas menguntungkan organisasi pemerintahan karena kebijakankebijakan yang disusun mempunyai kemungkinan yang jauh lebih besar untuk menjawab kebutuhan warga negara.

\section{Kerangka Kerja Baru, untuk Literasi Media Baru}

Topik literasi media era konvergensi media ini menjadi menarik, mengingat perdebatan tentang konsep literasi media (konvensional) sendiri masih menyisakan banyak pertanyaan yang belum disepakati oleh para penggiat literasi media (Hobbs, 1998). Di sisi lain, dengan kondisi seperti itu, konsep literasi media harus tetap dikembangkan untuk mengikuti perkembangan konvergensi media di era media baru.

Salah satu yang akan menjadi perhatian untuk mengawali bagian ini adalah konsep kerangka kerja literasi media baru yang ditawarkan Chen, dkk., (2011). Konsep ini akan berusaha membedah literasi media baru yang menekankan dimensi teknis dan sosial budaya yang kemudian akan memberikan kerangka baru untuk secara sistematis mengkaji konsep literasi media baru. Seringkali, literasi media baru lebih banyak diartikan sebagai kombinasi keterampilan informasi, keterampilan literasi komputer konvensional, dan keterampilan komunikasi (atau literasi majemuk). Definisi tersebut tidak menyinggung tentang karakteristik khas dari media baru (yang merupakan media konvergen) dan bagaimana karakteristik ini mempengaruhi konsep literasi media di era media baru abad ke 21 (Chen, dkk., 2011).

Literasi media baru dipahami sebagai konvergensi semua literasi yang berkembang pada abad terakhir yang mencakup literasi klasik, literasi audiovisual, literasi digital, dan literasi informasi. Berdasar pada pemahaman itu, Chen, dkk., (2011) mengajukan kerangka untuk membedah literasi media baru di era konvergensi media. Bahwa literasi media baru dapat dipahami sebagai dua dimensi dari literasi consuming hingga literasi prosuming dan dari literasi fungsional hingga kritis.

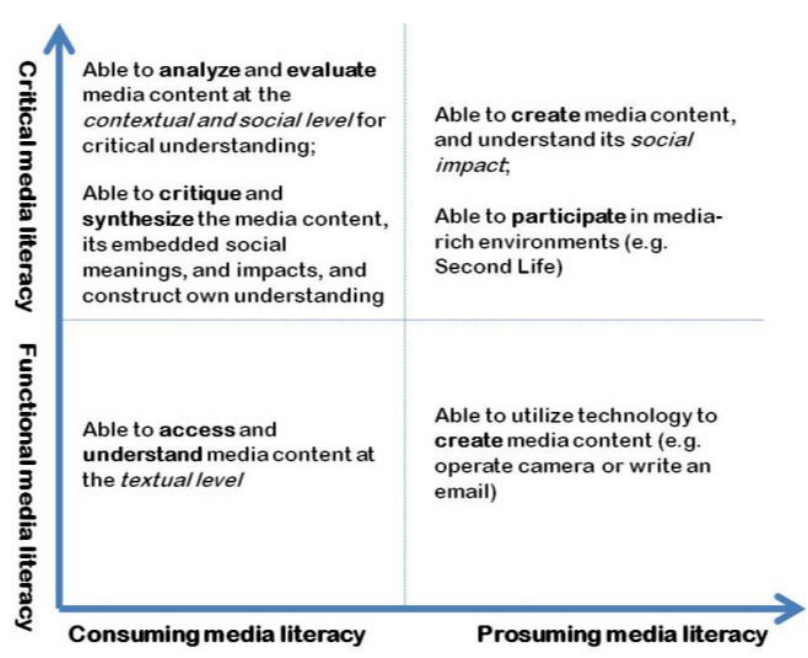

Gambar 1. Kerangka kerja literasi media baru dari Chen, dkk., (2011)

Dengan pembagian dari 1)Consuming functional; 2)Consuming Critical; 3) Prosuming functional; dan 4)Prosuming Critical; sebenarnya mereka telah berhasil memberikan gambaran besar atas kerangka definitif literasi media baru. Consuming functional membutuhkan kemampuan individu untuk mengakses konten media dan memahami makna tekstual. Consuming Critical melibatkan kemampuan individu untuk menafsirkan isi media dalam konteks sosial, ekonomi, politik dan budaya tertentu. Prosuming functional berfokus pada kemampuan untuk berpartisipasi dalam penciptaan konten media, sedangkan Prosuming Critical menggaris-bawahi interpretasi kontekstual individu dari konten media dalam kegiatan partisipasi mereka di media baru.

Dalam memetakan empat dimensi ini, Chen, dkk., banyak mengambil konsep dari Jankins dkk (2006). Budaya partisipatif menggeser fokus literasi dari sebuah ekspresi individu menjadi keterlibatan masyarakat. Untuk itu, Jenkins, dkk., memberikan gambaran inti 11 ketrampilan media literasi dalam bukunya. Kesebelas core media literacy 
skills ini yang sepertinya menjadi banyak acuan Chen, dkk., (2011) dalam menyusun 4 dimensi kerangka kerja literasi media ini.

Namun apa yang dituliskan Chen, dkk., ini dalam perkembangan mendapatkan respon dari Lin dkk., (2013). Dalam jurnal yang merupakan pengembangan kerangka kerja literasi media dari Chen, dkk., Lin bersama ketiga rekannya memberikan dua kritik besar atas kerangka kerja tersebut. Pertama, 4 dimensi dari Chen, dkk., dianggap masih kasar. Artinya, belum bisa memberikan batasan jelas dari kesemua dimensi tersebut dalam implementasinya, terutama dari dimensi fungsionalkritis. Lin dkk., memberi contoh bahwa akan sangat sulit membedakan definisi "memahami" (dari consuming functional) dan "menganalisis" (dari consuming critical). Oleh karenanya Lin bersama rekan-rekannya menawarkan 10 definisi yang lebih detil untuk lebih mempertegas perbedaan dari keempat dimensi Chen dkk. Kesepuluh dimensi tersebut antara lain consuming skill, understanding, analysis, synthesis, evaluation, prosuming skill, distribution, production, participation, dan creation.

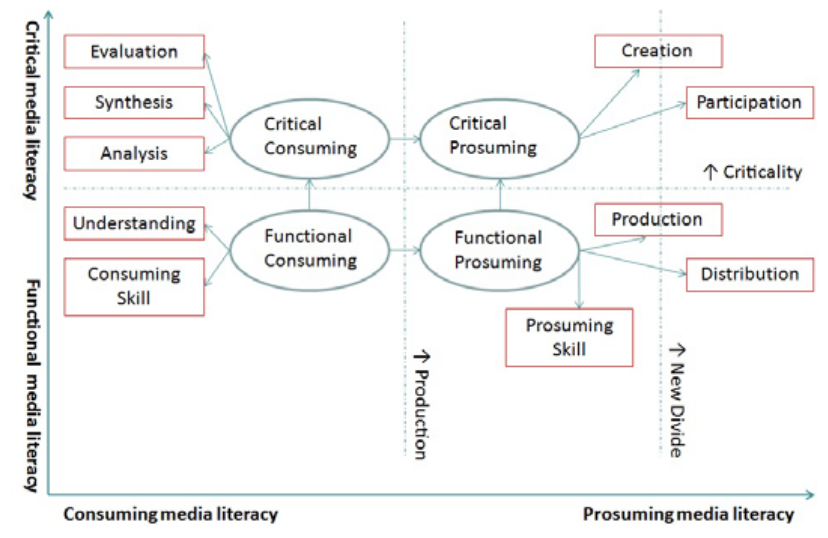

Gambar 2. Kerangka Kerja literasi media baru dari Lin, dkk., (2013)

Chen, dkk.,(2011) dan Lin, dkk., (2013) menjadikan level prosuming critical sebagai tingkatan tertinggi dalam literasi media baru. Senada Jenkins (2006) menjadikan keterampilan negotiation menjadi ketrampilan tertinggi dalam studinya. Negotiation skill sendiri artinya bagaimana menjadi kritis dengan menegosiasikan beragam sumber informasi yang disediakan media baru era konvergensi dengan tetap memperhatikan konteks sosial budaya. Dengan gambaran besar kerangka kerja literasi media baru ini, penelitian ini akan menggunakan kerangka kerja utama yang ditawarkan oleh Lin, dkk (2013) untuk mengetahui tingkat literasi media sosial humas pemerintah daerah.

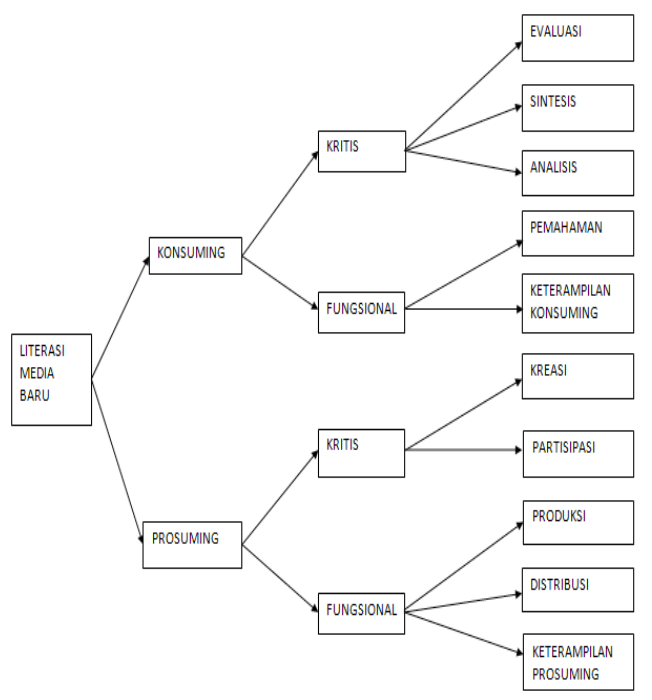

\section{Gambar 3. Kerangka Konseptual Literasi Media Baru (Lin dkk, 2013) yang akan digunakan dalam penelitian ini}

\section{METODE}

Penelitian ini menggunakan paradigma positivistik. Menurut Neuman, paradigma postivistik melihat ilmu sosial sebagai metode yang terorganisir dengan logika deduktif (Neuman, 2003, p.66; dalamAgostinho, 2005). Penelitian ini menggunakan pendekatan kuantitatif, metode yang digunakan adalah survei. Metode survei digunakan karena dianggap tepat mendapatkan deskripsi tingkat literasi media baru pada pegawai Humas Pemerintah di daerah. Metode survei secara deskriptif digunakan untuk mendapatkan gambaran secara sistematis tentang karakteristik populasi tertentu atau bidang tertentu secara faktual dan cermat (Isaac dan Michael dalam Rakhmat, 2007).

Pemerintah daerah yang ingin dilihat tingkat literasi media sosialnya kali ini adalah mereka yang telah merasa siap melawan hoax. Oleh karenanya, peneliti 
memilih daerah yang telah mendeklarasikan anti hoax sebagai tanda kesiapan melawan hoax. Populasi dalam penelitian ini adalah pegawai Humas Pemerintah yang daerahnya ikut menyatakan Deklarasi Anti Hoax yakni di Provinsi Jawa Tengah terdapat 6 (lima) lembaga Humas Pemerintah Kabupaten/ Kota (Semarang (kabupaten dan kota), Wonosobo, Solo, Banyumas, dan Blora); di Daerah Istimewa Yogyakarta terdapat satu lembaga Humas Pemerintah, yakni Humas Pemerintah Kota Yogyakarta; dan satu lagi di Provinsi Bali, yaitu Humas Pemerintah Provinsi Bali yang terhitung paling akhir mendeklarasikan anti hoax.

Jumlah responden di setiap Humas Daerah ditetapkan dengan teknik sampling qouta, di mana di setiap lembaga Humas Pemerintah Kabupaten/Kota diambil sejumlah 10 orang pegawai. Sampling diambil pada asumsi error $\pm 5 \%$ di mana derajat perbedaan antara sampel dan populasi dalam survei diperkirakan $\pm 5 \%$ pada tingkat kepercayaan 95\%. Dari 10 responden tiap pemerintah daerah tersebut terdiri dari seluruh pejabat struktural di lingkungan humas pemerintah, para staf yang berkaitan langsung mengelola media sosial resmi humas pemerintah, dan juga para staf yang baik secara langsung maupun tidak langsung membantu pengelolaan media sosial resmi tersebut.

Instrumen penelitian disusun berdasarkan kerangka kerja yang ditawarkan Lin, dkk (2013). Instrument tersebut telah melalui uji validitas dan reliabilitas. Untuk menguji validitas instrumen dalam penelitian ini menggunakan pengujian validitas konstruksi (construct validity). Untuk menguji validitas konstruksi, dapat digunakan pendapat dari ahli (judgment experts). Dalam hal ini setelah instrumen disusun, maka selanjutnya dikonsultasikan dengan konsultan dalam penelitian ini yakni seorang dosen yang spesialis mengajar ilmu komunikasi pada salah satu universitas ternama di DIY.

Instrumen yang disusun berupa kuesionare telah melalui uji reliabilitas dan instrumen tersebut sudah dinyatakan reliabel. Pengujian dilakukan pada karyawan ASN BPPKI Yogyakarta yang dinilai dapat mewakili karyawan Humas Pemerintah Daerah dalam segi usia, gender, dan kompetensinya sekaligus sama-sama menjabat sebagai ASN. Uji reliabilitas dalam penelitian ini menggunakan Analisis Varians Anova Hoyt (Sugiyono, 2014, hal. 132).

Instrumen yang digunakan pada penelitian ini berupa pertanyaan-pertanyaan yang akan menguji pengetahuan dan pemahaman responden tentang seluruh indikator dalam dimensi dan tingkatan dari kerangka kerja Lin. Penliaian masing-masing aspek akan diberikan skor o-10o. Hasil dari penilaian tersebut akan menunjukkan seberapa besar pengetahuan dan pemahaman literasi media baru para pegawai humas pemerintah ini.

Peneliti menyadari bahwa setiap memilih pendekatan dan metode, memiliki sebuah keterbatasan. Penelitian ini hanya akan meneliti kompetensi pegawai Humas Pemerintah Daerah berkaitan dengan penggunaan media baru (internet) khususnya melalui media sosial. Maka, hal yang berkaitan dengan kompetensi pegawai Humas lainnya tidak bisa dibahas dalam penelitian ini. Objek penelitian ini dalam jumlah terbatas yakni hanya pegawai Humas Pemerintah Daerah yang mendeklarasikan 'Anti Hoax', sehingga hasil penelitian ini belum dapat digeneralisasikan pada Humas Pemerintah Daerah lainnya

\section{HASIL DAN PEMBAHASAN}

Penelitian ini telah berhasil mengumpulkan data dari 10 responden pada masing-masing pemerintah daerah yang ditetapkan sebagai objek penelitian. Di beberapa daerah seperti Kabupaten Wonosobo, Kabupeten Semarang, dan Kota Yogyakarta, humas pemerintah daerah yang sebelumnya menjadi bagian dibawah Sekretaris Daerah telah bergabung menjadi satu dengan Dinas Komunikasi dan Informatika (Diskominfo). Perpindahan ini berlaku per Januari 2017. Perpindahan ini merespon diterbitkannya Peraturan Pemerintah nomor 18 tahun 2016 yang 
merupakan turunan dari Undang-Undang nomor 23 tahun 2014 tentang Pemerintah Daerah. Pada pemerintah daerah Kota/ Kabupaten tersebut, maka yang dijadikan responden adalah bidang atau seksi di Diskominfo yang memegang peran dan fungsi humas pemerintah daerah.

\section{Analisis Antar-Indikator}

Hasil yang cukup menggembirakan jika melihat data yang tersaji pada tabel 1 . Tidak ada satupun daerah yang mendapatkan nilai dengan klasifikasi rendah. Data pun didominasi dengan warna hijau, artinya sebagian besar hasil yang deperoleh adalah nilai dengan klasifikasi tinggi dengan rentang nilai dari 66,67 sampai 10o. Dilihat dari perolehan nilai rata-rata semua indikator, Kota Semarang mendapatkan nilai tertinggi dengan nilai rata-rata 77,84. Kemudian disusul kabupaten Blora dengan nilai yang hanya terpaut 0,12 poin dari Kota Semarang. Sedangkan provinsi bali dan kabupaten semarang mendapatkan nilai terendah dengan masing-masing mendapatkan nilai rata-rata 65,52 dan 65,76.

Jika berbicara literasi media sosial para pegawai humas pemerintah secara umum, ternyata tidak ada daerah yang tidak melek media sosial dilihat dari dominasi nilai tinggi yang diperoleh. Namun, bagi Lin dkk., (2013) untuk melihat literasi media baru harus dilihat dari masing-masing indikator, karena beberapa indikator dan indikator lainnya saling terkait.

Dimensi yang pertama akan dibahas adalah dimensi consuming-functional. Pada dimensi consuming-functional akan terlihat kemampuan pegawai humas pemerintah untuk mengakses konten media dan memahami makna tekstual. Indikator pertama dalam dimensi ini adalah consuming skill. Nilai rata-rata yang diperoleh pada indikator ini merupakan nilai terendah dari keseluruhan aspek. Nilai yang diperoleh tiap daerah juga tidak ada satupun yang mendapat nilai tinggi. Artinya keterampilan teknis mengkonsumsi isi media dari para pegawai humas pemerintah hanya pada level sedang dan merupakan ketrampilan yang paling lemah dibanding ketrampilan lainya. Indikator ini seperti: pegawai humas pemerintah mengetahui bagaimana mengoperasikan komputer, bagaimana untuk mencari/menemukan informasi

Tabel 1. Literasi Media Sosial Pegawai Humas Pemerintah di 8 Daerah

\begin{tabular}{|l|l|l|l|l|l|l|l|l|l|}
\hline Indikator & Ygy & Bali & Ska & Kb.Smg & Bny & Blr & Wnb & Smg & MEAN \\
\hline \multicolumn{8}{|c|}{ Consuming-Functional } \\
\hline Consuming Skill & 58.87 & 60.67 & 54.47 & 49.87 & 58.13 & 62.80 & 61.80 & 57.73 & 58.04 \\
\hline Understanding & 59.80 & 70.85 & 70.85 & 52.65 & 51.35 & 67.60 & 70.20 & 78.65 & 65.24 \\
\hline \multicolumn{8}{|c|}{ Prosuming-Functional } \\
\hline Prosuming Skill & 71.70 & 76.70 & 80.90 & 70.05 & 72.55 & 76.75 & 75.05 & 80.05 & 75.47 \\
\hline Distribution & 62.00 & 53.00 & 54.00 & 60.00 & 51.00 & 81.00 & 62.00 & 66.00 & 61.12 \\
\hline Production & 85.00 & 87.48 & 85.00 & 87.52 & 77.52 & 87.52 & 85.00 & 80.00 & 84.38 \\
\hline \multicolumn{8}{|c|}{ Consuming-Critical } \\
\hline Analysis & 80.00 & 47.50 & 65.00 & 62.50 & 67.50 & 80.00 & 77.50 & 77.50 & 69.69 \\
\hline Synthesis & 74.00 & 68.00 & 70.00 & 72.00 & 74.00 & 94.00 & 86.00 & 92.00 & 78.75 \\
\hline Evaluation & 67.50 & 52.50 & 72.50 & 80.00 & 85.00 & 80.00 & 92.50 & 87.50 & 77.19 \\
\hline \multicolumn{8}{|c|}{ Prosuming-Critical } \\
\hline Participation & 72.00 & 76.00 & 70.00 & 58.00 & 76.00 & 70.00 & 74.00 & 84.00 & 72.50 \\
\hline Creation & 50.00 & 54.00 & 76.00 & 56.00 & 46.00 & 72.00 & 56.00 & 72.00 & 60.25 \\
\hline MEAN & 69,84 & 65,52 & 69,77 & 65,76 & 68,30 & 77,72 & 75,40 & 77,84 & 70.26 \\
\hline
\end{tabular}

Sumber: Olah Data Peneliti 
dalam internet, bagaimana menggunakan teknologi informasi (misalnya Internet), dan sebagainya. Meskipun terbilang cukup dasar, ketrampilan ini cukup penting dan mempengaruhi keseluruhan aktifitas para pegawai humas pemerintah dalam bermedia sosial. Seperti contohnya pada salah satu pertanyaan yang ada pada indikator consuming skill yang mempertanyakan tentang keamanan link yang diperoleh melalui mesin pencari di internet. Terdapat $53 \%$ yang menjawab bahwa semua link tersebut aman untuk diakses, 2\% tidak menjawab, dan hanya $45 \%$ yang menyatakan tidak semua link aman diakses. Padahal jika mengacu pada banyaknya virus, malware, serta informasi hoax, link yang diberikan mesin pencari belum tentu aman untuk diakses.

Indikator kedua adalah indikator understanding. Nilai rata-rata yang diperoleh indikator ini masih sama dengan indikator sebelumnya yaitu masih pada klasifikasi nilai sedang. Artinya para pegawai humas ini memiliki kemampuan sedang dalam memahami makna dari isi media pada tingkat literal. Contohnya termasuk kemampuan untuk menangkap pesan orang lain, juga ide-ide individu yang dipublikasikan pada platform yang berbeda (misalnya buku, video, blog, Facebook, dll), dan untuk menafsirkan makna bentuk pendek baru atau emoticon. Chen dkk., (2011) juga menegaskan bahwa keterampilan ini hanya pada tingkat tekstual saja. Namun tidak seperti indikator consuming skill, terdapat lima daerah dengan nilai tinggi pada indikator understanding. Jika mengacu pada variabel usia responden, daerah-daerah yang mendapat nilai tinggi cenderung memiliki lebih banyak pegawai dengan usia dibawah 40 tahun. Faktor usia ini dimungkinkan mempengaruhi karena banyak bahasa, makna pendek baru, dan emoticon, lahir sebagian besar dari tren pergaulan anak muda/remaja. Sehingga akan sedikit kesulitan bagi generasi tua untuk mengikutinya.

Beralih pada dimensi prosuming functional untuk mengetahui tingkat kemampuan para pegawai humas pemerintah daerah untuk berpartisipasi dalam penciptaan konten media. Dimensi ini akan menekankan tentang penggunaan berbagai teknologi untuk membuat, mengedit, dan menyebarkan pesan media. Tiga indikator yang berada didalamnya adalah prosuming skill, distribution, dan production.

Nilai reratayang diperoleh pada indikator prosuming skill adalah tinggi dengan nilai 75,47. Keseluruhan daerah juga mendapat nilai tinggi yang menandakan tidak adanya kesenjangan pengetahuan antar pegawai humas antar daerah untuk indikator ini. Nilai yang tinggi ini menunjukkan bahwa para pegawai humas di semua daearh penelitian telah memiliki satu set keterampilan teknis yang cukup baik, yang diperlukan untuk menghasilkan/menciptakan isi media. Seperti misalnya, Para pegawai humas telah memiliki kemampuan untuk membuat account komunikasi secara online (misalnya MSN, Skype, Blog, Gmail, dan Facebook), serta untuk menggunakan perangkat lunak untuk menghasilkan berbagai produk digital (misalnya gambar, klip video, dan flash). Bersama-sama dengan dua indikator berikutnya (yaitu, distribution dan production), akan menggambarkan tentang penggunaan berbagai teknologi untuk membuat, mengedit, dan menyebarkan pesan media.

Dominasi nilai tinggi tidak terlihat pada indikator distribution. Pada indikator ini, 7 dari 8 daerah mendapat nilai sedang. Nilai rerata dari delapan daerah pun juga hanya pada tingkat sedang. Artinya, para pegawai humas pemerintah ini memiliki kemampuan sedang untuk menyebarkan informasi yang ada di tangan mereka. Dibandingkan dengan prosuming skill, distribution cenderung melibatkan proses berbagi. Semakin rendah nilai distribution maka akan semakin tinggi peluang para pegawai humas pemerintah daerah melakukan kesalahan dalam menggunakan fungsi build-in pada situs jaringan sosial untuk berbagi perasaan mereka (misalnya seperti suka / tidak suka), untuk berbagi pesan media, dan untuk menilai / orang untuk produk / jasa.

Indikator prosuming-functional selanjutnya adalah production. Indikator 
production ini merupakan indikator dengan nilai tertinggi. Dengan nilai rerata 84,38 menggambarkan bahwa para pegawai humas pemerintah daerah di delapan daerah ini telah memiliki kemampuan yang baik dalam menduplikasi (sebagian atau seluruhnya) atau mencampurkan isi media. Indikator production ini termasuk pemindaian (atau mengetik) dokumen hardcopy ke dalam format digital, memproduksi klip video dengan mencampur gambar dan materi audio, dan mencoret-coret online melalui media sosial.

Beranjak pada tingkatan critical media literacy yang memiliki dua dimenasi, consuming-critical dan prosuming-critical. Pada consuming-critical terdiri dari tiga indikator yaitu analysis, synthesis, dan evaluation. Dimensi consuming-critical ini akan menggambarkan kemampuan para pegawai humas pemerintah daerah dalam menafsirkan isi media dalam konteks sosial, ekonomi, politik dan budaya tertentu.

Pada indikator analysis, nilai rerata yang didapatkan masuk dalam klasifikasi tinggi dengan 69,69. Meski rerata delapan daerah tinggi, ada tiga daerah yang hanya mendapat nilai rendah, yaitu Provinsi Bali, Kota Surakarta, dan Kabupaten Semarang. Indikator ini menggambarkan pada kemampuan para pegawai humas pemerintah untuk mendekonstruksi pesan media. Tidak seperti pemahaman di level understanding, indikator ini dapat dilihat sebagai 'analisis tekstual' semiotik (Share, 2002, dalam Lin dkk., 2013) yang berfokus pada bahasa, genre, dan kode beberapa jenis dan media (misalnya berdasarkan print, digital, dll). Jika mengacu pada Thoman dan Jolls (2008, dalam Lin dkk., 2013), para pegawai humas telah memiliki kesadaran mengenai bagaimana produksi pesan (misalnya pemahaman media, bagaimana pesan dibangun), Format (misalnya pembangunan pesan media yang menggunakan bahasa kreatif dengan aturan tertentu), dan penonton (misalnya interpretasi pesan media akan bervariasi pada seluruh individu) ketika mereka mendekonstruksi pesan media. Dari data tersebut juga terlihat bahwa sebagian besar pegawai humas pemerintah daerah tersebut telah melihat isi media tidak sebagai konveyor netral realitas, tetapi mengakui pembangunan pesan media sebagai proses subjektif dan sosial.

Indikator selanjutnya adalah indikator Synthesis. Pada indikator ini, semua daearh mendapatkan nilai tinggi. Ini menandakan bahwa para pegawai humas pemerintah daerah telah memiliki kemampuan yang sangat baik dalam mencampur konten media dengan mengintegrasikan sudut pandang mereka sendiri serta dalam merekonstruksi pesan media. Para pegawai humas ini telah terampil dalam membandingkan berita dengan tema yang sama dari sumber yang berbeda. kemampuan membandingkan informasi ini termasuk kemampuan yang wajib dimiliki di era tsunami informasi. Namun, Jenkins et al., (2006) secara implisit mengingatkan, synthesis juga melibatkan indikator analysis yang dibahas sebelmnya. Jika kemampuan analysis lebih rendah, maka juga akan mempengaruhi kemampuan synthesis ini. Nyatanya pada data yang diperoleh, nilai analysis mendapatkan nilai rerata yang lebih rendah (terpaut hampir 10 poin) dibanding nilai synthesis, meskipun masih termasuk klasifikasi tinggi. Artinya, perbedaan nilai ini perlu dipertimbangkan dalam melihat kemampuan sebenarnya pada indikator synethesis.

Indikator puncak dalam dimensi consuming-critical adalah indikator evaluation. Dari data terlihat cukup memuaskan dengan nilai tinggi yang diperoleh indikator ini. Disebut indikator puncak karena indikator evaluasi ini melibatkan proses pengambilan keputusan yang tidak ditekankan secara eksplisit pada indikator synthesis dan analysis. Dengan nilai rerata yang tinggi, menggambarkan kemampuan yang sangat baik dari para pegawai humas pemerintah daerah untuk mempertanyakan, mengkritik, dan menantang kredibilitas isi media. Dibandingkan dengan indikator analysis dan synthesis sebelumnya, indikator ini merupakan level yang lebih tinggi atas tingkat kritis, meskipun kesemuanya mengakui 
bahwa isi media hanyalah representasi yang dibangun manusia. Tingginya nilai indikator ini menunjukkan humas pemerintah daerah telah dapat menafsirkan isi media dengan mempertimbangkan isu-isu seperti identitas, relasi kuasa, dan ideologi.

Beralih pada indikator dalam dimensi prosuming-critical. Yang pertama adalah indikator partisipation. berbeda dengan tiga indikatorprosuming-functional,partisipation membutuhkan lebih banyak kekritisan dari individu. Hampir semua daerah mendapat nilai tinggi dengan nilai rerata delapan daerah yang juga tinggi. Dari data tersebut menggambarkan kemampuan yang sangat baik dari para pegawai humas pemerintah daerah untuk berpartisipasi secara interaktif dan kritis dalam lingkungan media baru. Karena disebutkan interaktif, indikator ini menekankan pada interaksi bilateral antara individu-individu. Dari nilai yang tinggi pada indikator ini, salah satunya menggambarkan peran serta para pegawai humas pemerintah untuk secara aktif ikut membangun dan memperbaiki salah satu ide-ide orang lain dalam media sosial. Sesuai gambaran Jenkins (2004) mengambil konsep kecerdasan kolektif, para pegawai humas pemerintah daerah ini telah aktif terlibat menyatukan pengetahuan dan membandingkan catatan dengan orang lain untuk mencapai tujuan bersama. Dengan kritis, indikator ini juga terfokus pada kesadaran para pegawai humas pemerintah daerah dari nilai-nilai sosial budaya, ideologi, dan relasi kuasa yang tertanam dalam partisipasi media mereka.

Indikator terakhir adalah indikator creation. Berbeda dengan indikator partisipation yang mendapat nilai tinggi, indikator creation hanya mendapat nilai rerata sedang. Artinya, para pegawai humas pemerintah daerah hanya memiliki kemampuan sedang dalam membuat isi media terutama dengan pemahaman kritis tertanam nilai-nilai sosialbudayadan masalah ideologi. Dibandingkan dengan distribution dan production, indikator creation lebih melibatkan kekritisan dari para pegawai humas pemerintah. Meskipun sama-sama masuk pada kategori prosuming critical, perbedaan antara creation dan partisipation harus dicatat. Tidak seperti partisipation, creation biasanya membutuhkan inisiatif dari para pegwai humas dari pada interaksi bilateral antara individu. Misalnya, inisiasi pertama dari sebuah thread dengan kekritisan akan penciptaan; sedangkan refleksi berikutnya (komentar/reaksi dari thread tersebut) akan dilihat sebagai tindakan partisipasi. Indikator ini menggambarkan kemampuan yang sedang dari para pegawai humas pemerintah daearh untuk secara kritis membuat tulisan pada halaman media sosial mereka, untuk memasukkan karya seni asli secara online, atau untuk mencampur konten online menjadi kreasi mereka sendiri.

\section{Analisis Antar-Dimensi}

Pada Bagian ini akan mencoba membandingkan nilai rerata antar indikator yang membentuk empat dimensi dalam kerangka kerja literasi media baru dari Lin, dkk., (2013). Empat dimensi tersebut terdiri dari dimensi consuming-functional, consuming-critical, prosuming-functional, dan prosuming-critical. Perbandingan nilai yang diperoleh antar dimensi terlihat pada tabel berikut ini.

Tabel 2. Nilai rata-rata antardimensi

\begin{tabular}{|l|l|l|l|}
\cline { 2 - 4 } \multicolumn{1}{c|}{} & $\begin{array}{l}\text { Consuming } \\
\text { media literacy }\end{array}$ & $\begin{array}{l}\text { Prosuming } \\
\text { media literacy }\end{array}$ & MEAN \\
\hline $\begin{array}{l}\text { Functional } \\
\text { media } \\
\text { literacy }\end{array}$ & 61.64 & 73.66 & 67.65 \\
\hline $\begin{array}{l}\text { Critical } \\
\text { media } \\
\text { literacy }\end{array}$ & 75.21 & 66.37 & 70.79 \\
\hline
\end{tabular}

Sumber: Olah Data Peneliti

Dari data tersebut terlihat bahwa dimensi consuming-critical mendapat nilai ratarata tertinggi dibanding dimensi lainnya. Artinya kemampuan para pegawai humas pemerintah daerah dalam menafsirkan isi media dalam konteks sosial, ekonomi, politik, dan budaya tertentu lebih tinggi dibanding kemampuan lain dalam literasi media sosial. Hal ini dimungkinkan karena kedekatan pekerjaan profesi humas dengan para pekerja media dan media massa. Terutama para pengelola media sosial pada 
humas pemerintah daerah yang sebagian besar berada di bidang yang menangani media dan pemberitaan. Profesi keseharian mereka pun dituntut untuk memahami logika kerja media agar berita-berita yang mereka hasilkan tentang pemerintah daerah banyak terbit di media massa. Dengan kedekatan tersebut, membuat para pengelola media sosial ini menjadi terbiasa dalam merepresentasikan isi media secara kritis. Meskipun beberapa dari mereka tidak sadar bahwa apa yang mereka lakukan ketika membaca isi media telah berpegang pada paradigma kritis seperti yang diterangkan Jenkins, dkk., (2006), karena sebagian dari mereka tidak memiliki latar belakang pendidikan yang dekat dengan studi media ataupun komunikasi.

Sedangkan untuk nilai terendah ada pada dimensi consuming-functional yang terbilang merupakan dimensi dasar dalam literasi media sosial. Rendahnya nilai rerata dimensi consuming-functional ini menggambarkan rendahnya kemampuan para pegawai humas dalam mengakses konten media sosial dan memahami makna tekstual yang ada didalamnya. Dalam analisis antar indikator sebelumnya, muncul kemungkinan faktor usialah yang banyak mempengaruhi dimensi ini. pada pemerintah daerah yang respondennya dominan berusia muda, mendapatnya nila yang lebih tinggi dibanding pemerintah daerah yang sedikit respondennya berusia muda. Dimensi ini memang terbilang dimensi teknis dasar dalam mulai mengakses dan mengkonsumsi isi pada media baru khususnya media sosial. Namun, dengan rendahnya nilai pada dimensi ini, memungkinkan semakin besar peluang para pegawai humas pemerintah daerah melakukan kesalahan teknis dalam penggunaan media sosial.

\section{SIMPULAN}

Dengan tidak adanya nilai rendah, maka dapat disimpulkan bahwa para pengelola media sosial humas pemerintah daerah yang telah menggelar deklarasi anti hoax telah memiliki literasi media sosial yang cukup.
Jika melihat perbandingan antar dimensi, nilai rata-rata critical media literacy lebih tinggi jika dibanding dengan functional media literacy. Temuan ini menarik, karena jika melihat dari indikator-indikator yang menyusunnya, tingkatan functional lebih banyak berbicara tentang hal teknis yang cenderung lebih mudah dipelajari dari pada tingkatan critical yang menuntut tingkat kekritisan seseorang. Artinya, pegawai humas pemerintah daerah sebenarnya telah memiliki modal besar dalam literasi media sosial sekaligus untuk upaya pemberantasan hoax. Untuk mengoptimalkan fungsi dan peran humas pemerintah daerah dalam usaha menangkal hoax hanya perlu meningkatkan pengetahuan dan ketrampilan yang sifatnya teknis tentang media baru dan media sosial. Sedangkan bagian tersulit dari literasi media sosial, yaitu selalu melibatkan tingkat kekritisan para pegawai humas pemerintah daerah dalam aktifitas media sosial, telah banyak yang menguasainya.

Terdapat beragam model berbeda yang telah dihasilkan para ilmuan litererasi media baru, namun kesemuanya menjadikan nilai kritis atas informasi menjadi tujuan akhir dari literasi media baru (Chen, et al., 2011; Lin, et al., 2013; Jenkins, et al., 2006). Sebagian besar pegawai humas pemerintah daerah tersebut telah menjadi kritis dalam artian mereka menyadari bahwa konten media baru adalah ciptaan manusia atas dasar kepentingan. Dasar itulah yang menjadikan persepsi bahwa tidak ada "kebenaran" yang sebenar-benarnya dalam media baru. Sikap kritis inilah yang akan memposisikan sudut pandang para pegawai humas atas "kebenaran" semu di dunia maya. Artinya sikap kritis ini mampu membentengi diri atas fenomena realitas semu yang digambarkan oleh Piliang (2010). 


\section{DAFTAR PUSTAKA}

Bertot, J. C., Jaeger, P., Munson, S., \& Glaisyer, T. (2010). Social Media Technology and Government Transparency. IEEE Computer Society, 43(11), 53-59.

Chen, D.-T., Wu, J., \& Wang, Y.-M. (2011). Unpacking New Media Literacy. Journal on Systemics, Cybernetics and Informatics, 84-88.

Cutlip, S. M., Center, A. H., \& Broom, G. (2000). Effective Public Relations. New Jersey: Prentice Hall International.

Graham, M., \& Avery, E. J. (2013). Government Public Relations and Social Media: An Analysis of the Perceptions and Trends of Social Media Use at the Local Government Level. Public Relations Journal, 7(4). Diambil kembali dari https://pdfs.semanticscholar.org/10e4 /2979c35f479baca1bfo4fioc1641a9c8o 3e3.pdf

Grunig, J. E., \& Hunt, T. (1992). Model of Public Relations and Communication. Dalam J. E. Grunig (Penyunt.), Exellence in Public Relations and Communications Management. New Jersey: Lawrence Erlbaum.

Hand, L. C., \& Ching, B. D. (2011). You have one friend request: An exploration of power and citizen engagement in local governments. Administrative Theory and Praxis, 33, 362-382.

Hobbs, R. (1998). The Seven Great Debates in the Media Literacy Movement. Journal of Communication, 48(1), 16-32.

Hobbs, R. (2010). News Literacy: What Works and What Doesn't. Association for Education in Journalism and Mass Communication (AEJMC) Conference. Denver, Colorado. Dipetik 3 7, 2017, dari http://works.bepress.com/ reneehobbs/12/

Jenkins, H. (2004). Cultural Logic of Media Convergence. Journal of Cultural Studies, 33-43.
Jenkins, H. (2006). Convergence Culture: When Old and New Media Collide. NY: New York University Press.

Jenkins, H., Clinton, K., Purushotma, R., Robinson, A. J., \& Weigel, M. (2006). Confronting the Challenges of Participatory Culture: Media Education for the 21st Century (White Paper). Diambil kembali dari http:// mitpress.mit.edu/sites/default/files/ titles/free_download/9780262513623_ Confronting_the_Challenges.pdf

Kietzmann, J. H., Hermkens, K., McCarthy, I. P., \& Silvestre, B. S. (2011). Social Media? Get Srious! Understanding the Funcional Building Blocks of Social Media. Business Horizons, 241-251.

Kovach, B., \& Rosenstiel, T. (2011). Blur: How to Know What's True in the Age of Information Overload. New York: Bloomsbury.

Levy, P. (2010). From social computing to reflexive collective intelligence: The IEML research program. Information Sciences, 71-94.

Lewandowsky, S., Oberauer, K., \& Gignac, G. E. (2013). NASA Faked the Moon Landing-Therefore, (Climate) Science is a Hoax: An Anatomy of the Motivated Rejection on Science. Psychological Science, 622-633.

Lin, T.-B., Li, J.-Y., Deng, F., \& Lee, L. (2013). Understanding New Media Literacy: An Explorative Theoretical Framework. Educational Technology \& Society, 16o170.

Lister, M., Dovey, J., Giddings, S., Grant, I., \& Kelly, K. (2009). New Media: A Critical Introduction (Second Edition ed.). New York: Routledge.

Marchi, R. (2012). Whith Facebook, Blogs, and Fake News, Teen Reject Journalistic "Objectivity". JournalofCommunication Inquiry, 36(3), 246-262.

Piliang, Y. A. (2009). Posrealitas: Realitas Kebudayaan dalam Era Postmetafisika. Yogyakarta: Jalasutra. 
Piliang, Y. A. (2010). Dunia yang Dilipat (edisi keempat). Bandung: Matahari.

Potter, J. W. (2001). Media Literacy (second edition ed.). London: Sage Publications.

Potter, J. W. (2004). Theory of Media Literacy: A Cognitive Approach. London: Sage Publication.

Rakhmat, J. (2007). Metode Penelitian Komunikasi. Bandung: Rosdakarya.

Rosenbaum, J. E., Beentjes, J. W., \& Konig, R. P. (2008). Mapping Media Literacy: Key Conceptsand Future Directions. Annals of the International Communication Association, 32(1), 313-353.

Schmidt, H., \& Root. (2014). Developig Media Competence and Work-Related Informational Behavior in Academic Studies. EduRe Journal, 90-108. Diambil kembali dari http://edure.org/ EduReJournalVoliNi/EduRe_V1_I1_ P7.pdf

Seitel, F. P. (2004). The Practice of Public Relations. New Jersey: Pearson Prentice Hall.

Sugiyono. (2014). Metode Penelitian Kuantitatif, Kualitatif, dan RED. Bandung: Alfabeta.

Vanwynsberghe, H., Boundry, E., \& Verdegem, e. P. (2011). Mapping Social Media Literacy: Towards a Conceptual Framework. IBBT-MICT-ICT UGENT. Diambil kembali dari http://emsoc.be/ wp-content/uploads/2012/o1/emsocWP2-MICT-deliverable1_14.pdf 